\title{
Effects of Curing Period of Livestock Droppings on the Growth and Yield of Okra (Abelmoschus esculentus L.) Varieties
}

\author{
S. Y. Abdulmaliq, ${ }^{1}$ Y. A. Abayomi, ${ }^{2}$ M. O. Aduloju, ${ }^{3}$ and O. Olugbemi ${ }^{2}$ \\ ${ }^{1}$ Department of Crop Production, Ibrahim Badamosi Babangida University, Lapai, Niger State, Nigeria \\ ${ }^{2}$ Department of Agronomy, University of Ilorin, PMB 1515, Ilorin, Kwara, Nigeria \\ ${ }^{3}$ Department of Crop and Soil Science, Landmark University, PMB 1001, Omu-Aran, Kwara State, Nigeria
}

Correspondence should be addressed to O. Olugbemi; t.olugbemi@yahoo.com

Received 30 October 2015; Accepted 24 December 2015

Academic Editor: David Clay

Copyright (C) 2016 S. Y. Abdulmaliq et al. This is an open access article distributed under the Creative Commons Attribution License, which permits unrestricted use, distribution, and reproduction in any medium, provided the original work is properly cited.

A field study was carried out across two cropping seasons (2010 and 2011) to explore the effects of curing periods of cow dung and poultry droppings used in soil amendment on the performance of two okra (Abelmoschus esculentus L.) varieties: NHAe 47-3 and LD 88-1. The effects of cow dung and poultry droppings cured for 3, 6, and 9 weeks were compared to that of NPK fertilizer (100 kg N ha ${ }^{-1}$ and $60 \mathrm{~kg} \mathrm{ha}^{-1}$ each of $\mathrm{P}_{2} \mathrm{O}_{5}$ and $\mathrm{K}_{2} \mathrm{O}$ ) and a control (no amendment). The application of organic amendment cured for 3 to 6 weeks enhanced the growth and yield of okra when compared with inorganic fertilizer or the unamended soil across the two cropping seasons. Based on this outcome, the use of adequate quantity of livestock droppings cured for 3-6 weeks, in case of poultry dropping, and for 6 weeks, in case of cow dung, is recommended as an alternative to inorganic fertilizer. The variety NHAe 47-4 was also demonstrated to give better yield (1.73 and 2.18 $\left.\mathrm{tha}^{-1}\right)$ than LD 88-1 (1.63 and $\left.1.80 \mathrm{t} \mathrm{ha}^{-1}\right)$ in the years 2010 and 2011 , respectively.

\section{Introduction}

Okra, like any other indigenous vegetable, is widely cultivated, especially for its green tender fruit, and can be found in most local markets in Africa. The crop belongs to the family Malvaceae and the genus Abelmoschus which has two main species; A. esculentus (L.) Moench. and A. caillei (A. Chev.) Stevels [1].

Vegetable crop producers in the tropics are bedeviled with the problem of maintaining soil fertility. This is because the native fertility of most agricultural soils in this region is low and cannot support suitable crop production over a long period without the use of fertilizers $[2,3]$. This problem is further compounded by the scarcity and high cost of inorganic fertilizers which has forced farmers to make use of fertilizer rates that are lower than the optimum with its resultant reduction in yield. For instance, Mayong et al. [4] in their survey discovered that farmers applied less than half of the $120 \mathrm{~kg} \mathrm{~N} \mathrm{ha}^{-1}$ recommended for maize in the northern
Guinea savannah due to the problem of scarcity and high cost of inorganic fertilizer.

Akiri [5] has described soil fertility degradation as the second most serious constraint to food scarcity in Africa, and as Avery [6] has observed, the maintenance of soil fertility over a long period with inorganic fertilizer application has led to increased soil degradation and nutrient imbalance, resulting in deleterious effects on crop growth, quality, ecosystem, and soil health. There is therefore the need to explore alternative means of soil amendment in order to improve on the productivity of crops in general and vegetables in particular.

The use of organic fertilizer in soil amendment has a number of advantages. When added to the soil, organic fertilizer has been reported to influence many physicochemical and biological properties of the soil such as increased infiltration rate, reduced bulk density, aggregate stability, cation exchange capacity (CEC), and biological activities $[7,8]$. Additionally, organic fertilizer serves as slow-release reservoir for plant macronutrients, aids in plants micronutrient absorption, and 
facilitates water and air infiltration. It has however been argued that organic manures are usually late in nutrient mineralization. Hence, there is a need to cure organic manures in order to reduce the time of mineralization on the field.

In spite of the numerous advantages of organic fertilizers in soil amendment, not many works have been reported on their effects on growth and quality of vegetables in the tropics. Also, the roles of manure curing period on growth, yield, and quality of vegetables have not been given the necessary attention. This study was therefore carried out to determine the effects of curing periods of cow dung and poultry droppings manures on the growth and yield of okra varieties.

\section{Materials and Methods}

The experiment was carried out during the 2010 and 2011 cropping seasons at the Teaching and Research farm, Faculty of Agriculture, University of Ilorin, Ilorin, Nigeria (latitude $8^{\circ} 29^{\prime} \mathrm{N}$, longitude $4^{\circ} 35^{\prime} \mathrm{E}$; about $310 \mathrm{~m}$ above sea level). The field was cleared, ploughed and harrowed, and thereafter divided into raised beds with each plot measuring $4 \mathrm{~m} \times$ $5 \mathrm{~m}$. The experiment was laid out as $8 \times 2$ factorial in a randomized complete block design (RCBD), made up of 8 soil amendments and two okra varieties (LD 88-1 and NHAe 47-4), with the factorial combinations replicated four times. Pretreatment soil physicochemical analyses of the experimental site for the periods of the study were carried out following the International Institute of Tropical Agriculture (IITA) procedure [9], and the rainfall distribution and mean temperature of the area were obtained.

The soil amendments were manure (cow dung and poultry droppings) cured for 3, 6, and 9 weeks (labeled C3, C6, and C9 and P3, P6, and P9 for cow dung and poultry droppings, resp.), NPK (100 kg Nha ${ }^{-1}$ and $60 \mathrm{~kg} \mathrm{ha}^{-1}$ each of $\mathrm{P}_{2} \mathrm{O}_{5}$ and $\mathrm{K}_{2} \mathrm{O}$ ), and a control (no amendment, NA). The cow dung and poultry droppings were analysed for the pretreatment nutrient content before curing. Organic manures were applied at the rate of $10 \mathrm{tha}^{-1}$ a week before planting, while the inorganic fertilizer was applied in two equal doses at three and six weeks after planting. Okra seeds were planted at the rate of 3 seeds per hole at inter- and intrarow spacing of $40 \mathrm{~cm}$ and $30 \mathrm{~cm}$, respectively. The crop was thinned to two plants per hole at two weeks after emergence. Weeding was carried out manually at biweekly interval, and, for pest control, cypermethrin was used every two weeks prior to flowering.

Data collected include plant height, number of leaves per plant, and leaf area obtained from 5 randomly selected and tagged plants from each plot at 3, 5, 7, and 9 weeks after planting (WAP). Also recorded were days to first flowering and days to $50 \%$ flowering. The lengths of five randomly selected fruits were taken and the average recorded as pod length. The grooves of these pods were counted and the mean was recorded as number of grooves per pod. The weight of the fresh fruits harvested from the tagged plants was recorded and the average taken as pod fresh weight per plant. Also recorded was the cumulative yield per plot. Relative change over standard (RCS) and relative change over control (RCC)
TABLE 1: Pretreatment soil $(0-30 \mathrm{~cm})$ physical and chemical characteristics of the experimental sites in 2010 and 2011 cropping seasons.

\begin{tabular}{lcc}
\hline Soil properties & 2010 & 2011 \\
\hline $\mathrm{pH}\left(\mathrm{H}_{2} \mathrm{O}\right) 1: 1$ & 7.30 & 6.40 \\
Organic matter $(\mathrm{g} / \mathrm{kg})$ & 6.20 & 8.30 \\
Total organic carbon content $(\mathrm{g} / \mathrm{kg})$ & 3.60 & 4.80 \\
Total N (g/kg of soil) & 1.30 & 1.34 \\
Available P (Bray 1$)(\mathrm{mg} / \mathrm{kg})$ & 2.12 & 2.18 \\
Available K (cmol/kg) & 0.18 & 0.16 \\
Calcium $(\mathrm{cmol} / \mathrm{kg})$ & 1.10 & 3.10 \\
Magnesium $(\mathrm{cmol} / \mathrm{kg})$ & 1.60 & 1.30 \\
Sodium $(\mathrm{cmol} / \mathrm{kg})$ & 0.01 & 0.01 \\
CEC $(\mathrm{cmol} / \mathrm{kg})$ & 4.23 & 4.50 \\
Exchangeable acidity (cmol/kg) & 0.04 & 0.21 \\
Sand $(\mathrm{g} / \mathrm{kg})$ & 840 & 862 \\
Silt $(\mathrm{g} / \mathrm{kg})$ & 80 & 84 \\
Clay $(\mathrm{g} / \mathrm{kg})$ & 80 & 54 \\
Texture & Sandy loam & Sandy loam \\
\hline
\end{tabular}

TABle 2: Pretreatment nutrient content of cow dung (CD) and poultry droppings (PD) in 2010 and 2011.

\begin{tabular}{lcccc}
\hline Nutrient & \multicolumn{2}{c}{2010} & \multicolumn{2}{c}{2011} \\
& $\mathrm{CD}$ & $\mathrm{PD}$ & $\mathrm{CD}$ & $\mathrm{PD}$ \\
\hline $\mathrm{N}(\mathrm{g} / \mathrm{kg})$ & 0.96 & 1.32 & 0.89 & 1.46 \\
$\mathrm{P}(\mathrm{mg} / \mathrm{kg})$ & 0.99 & 1.02 & 0.98 & 1.05 \\
$\mathrm{~K}(\mathrm{cmol} / \mathrm{kg})$ & 0.86 & 0.92 & 1.09 & 1.20 \\
Organic C $(\mathrm{g} / \mathrm{kg})$ & 4.13 & 2.65 & 3.94 & 3.12 \\
\hline
\end{tabular}

in the yield from soil amendments were determined using the expressions described by Chien et al. [10]:

$$
\begin{aligned}
\operatorname{RCS}(\%) & =\frac{\text { Yield }_{\text {treatment }}}{\text { Yield }_{\text {chemical fertilizer }}} \times 100, \\
\operatorname{RCC}(\%) & =\frac{\text { Yield }_{\text {treatment }}-\text { Yield }_{\text {control }}}{\text { Yield }_{\text {chemical fertilizer }}-\text { Yield }_{\text {control }}} \times 100 .
\end{aligned}
$$

All data obtained were subjected to analysis of variance using Genstat Discovery 4 statistical package [11] and means separated using the least significant difference, at $5 \%$ probability level.

\section{Results}

The physicochemical analyses of the experimental site indicated that the soil of the area could be classified as sandy loam with a pH values of 7.3 and 6.4 for the 2010 and 2011 cropping seasons, respectively (Table 1). Table 2 displays the pretreatment nitrogen, phosphorus, and potassium content of the cow dung (CD) and poultry dropping (PD) used for the experiment in the two years. $\mathrm{CD}$ had higher nitrogen content than PD in the two years. A general overview of the weather data indicated that there was more rain in the 2011 cropping season $(1,795.7 \mathrm{~mm})$ compared with that of the preceding year $(1,046.6 \mathrm{~mm})$. The highest average monthly rainfall 
TABLE 3: Effects of cured organic amendments and varieties on the mean plant height $(\mathrm{cm})$ of okra in 2010 and 2011 cropping seasons.

\begin{tabular}{|c|c|c|c|c|c|c|c|c|}
\hline \multirow{2}{*}{ Treatment } & \multicolumn{2}{|c|}{3 WAP } & \multicolumn{2}{|c|}{$5 \mathrm{WAP}$} & \multicolumn{2}{|c|}{7 WAP } & \multicolumn{2}{|c|}{9 WAP } \\
\hline & 2010 & 2011 & 2010 & 2011 & 2010 & 2011 & 2010 & 2011 \\
\hline \multicolumn{9}{|c|}{ Soil amendment } \\
\hline $\mathrm{C} 3$ & 7.58 & 5.69 & 20.58 & 23.14 & 23.77 & 32.92 & 34.49 & 35.50 \\
\hline C6 & 7.30 & 5.46 & 21.50 & 25.97 & 24.77 & 35.50 & 36.64 & 40.02 \\
\hline C9 & 7.85 & 5.50 & 20.70 & 24.33 & 23.77 & 34.80 & 36.48 & 36.75 \\
\hline P3 & 8.30 & 6.59 & 23.15 & 27.20 & 27.47 & 38.38 & 38.38 & 41.70 \\
\hline P6 & 7.60 & 6.33 & 21.70 & 26.51 & 25.30 & 36.45 & 37.43 & 40.07 \\
\hline P9 & 7.63 & 5.76 & 21.38 & 24.55 & 24.77 & 34.90 & 36.50 & 39.97 \\
\hline NA & 6.71 & 5.59 & 19.60 & 21.86 & 23.35 & 32.27 & 33.65 & 33.55 \\
\hline NPK & 7.90 & 6.09 & 21.70 & 27.17 & 26.10 & 38.17 & 38.08 & 42.50 \\
\hline $\mathrm{SE} \pm$ & 0.418 & 0.628 & 1.303 & 2.082 & 0.779 & 1.889 & 1.857 & 1.505 \\
\hline $\operatorname{LSD}_{(0.05)}$ & 0.842 & ns & 2.624 & ns & 1.569 & 3.804 & 2.985 & 3.032 \\
\hline \multicolumn{9}{|l|}{ Variety } \\
\hline LD 88-1 & 8.18 & 6.06 & 28.84 & 25.16 & 25.21 & 35.88 & 37.15 & 39.52 \\
\hline NHAe 47-4 & 7.05 & 5.69 & 19.74 & 25.03 & 24.84 & 34.72 & 35.75 & 39.38 \\
\hline $\mathrm{SE} \pm$ & 0.209 & 0.314 & 0.651 & 1.041 & 0.39 & 0.944 & 0.929 & 0.753 \\
\hline $\operatorname{LSD}_{(0.05)}$ & 0.421 & ns & 1.312 & ns & ns & ns & ns & ns \\
\hline
\end{tabular}

ns: not significant; LSD: least significant difference $(p=0.05)$; WAP: weeks after planting; SE: standard error.

TABLE 4: Effects of cured organic soil amendment on the number of leaves of okra in 2010 and 2011 cropping seasons.

\begin{tabular}{|c|c|c|c|c|c|c|c|c|}
\hline \multirow{2}{*}{ Treatment } & \multicolumn{2}{|c|}{3 WAP } & \multicolumn{2}{|c|}{$5 \mathrm{WAP}$} & \multicolumn{2}{|c|}{7 WAP } & \multicolumn{2}{|c|}{9 WAP } \\
\hline & 2010 & 2011 & 2010 & 2011 & 2010 & 2011 & 2010 & 2011 \\
\hline \multicolumn{9}{|c|}{ Soil amendment } \\
\hline $\mathrm{C} 3$ & 4.38 & 4.71 & 5.63 & 6.65 & 7.08 & 8.46 & 6.06 & 9.27 \\
\hline C6 & 4.44 & 4.69 & 5.53 & 7.04 & 7.03 & 9.36 & 6.01 & 10.25 \\
\hline C9 & 4.31 & 4.50 & 5.63 & 6.70 & 7.20 & 7.56 & 5.81 & 8.29 \\
\hline P3 & 4.94 & 4.81 & 6.13 & 8.31 & 7.73 & 9.52 & 9.18 & 11.94 \\
\hline P6 & 4.75 & 4.45 & 5.75 & 7.56 & 7.18 & 8.94 & 6.81 & 10.61 \\
\hline P9 & 4.44 & 4.75 & 5.98 & 7.10 & 7.50 & 8.43 & 5.71 & 9.78 \\
\hline NA & 4.00 & 4.64 & 5.50 & 6.43 & 6.08 & 7.58 & 5.62 & 8.32 \\
\hline NPK & 4.56 & 4.75 & 6.00 & 7.70 & 7.58 & 9.29 & 6.92 & 11.85 \\
\hline $\mathrm{SE} \pm$ & 0.384 & 0.270 & 0.325 & 0.630 & 0.345 & 0.809 & 0.672 & 1.136 \\
\hline $\operatorname{LSD}_{(0.05)}$ & ns & ns & ns & ns & ns & ns & 1.352 & 2.287 \\
\hline \multicolumn{9}{|l|}{ Variety } \\
\hline LD 88-1 & 4.52 & 4.62 & 5.93 & 7.05 & 7.54 & 8.47 & 6.43 & 9.66 \\
\hline NHAe $47-4$ & 4.44 & 4.72 & 5.59 & 7.33 & 7.09 & 8.82 & 6.53 & 10.04 \\
\hline $\mathrm{SE} \pm$ & 0.192 & 0.139 & 0.163 & 0.315 & 0.170 & 0.405 & 0.52 & 0.568 \\
\hline $\operatorname{LSD}_{(0.05)}$ & ns & ns & 0.325 & ns & 0.343 & $\mathrm{~ns}$ & ns & ns \\
\hline
\end{tabular}

ns: not significant; LSD: least significant difference ( $p=0.05)$; WAP: weeks after planting; SE: standard error.

of $334.6 \mathrm{~mm}$ was obtained in September 2011; the highest average monthly rainfall in 2010 was $226.8 \mathrm{~mm}$ obtained in October (Figure 1).

The plant height of okra was significantly affected by the soil amendments at 3, 5, 7, and 9 WAP in the two cropping seasons. Poultry dropping cured for 3 weeks (P3) consistently resulted in significantly taller plants in 2010 (Table 3). In 2011, however, the result was only obtained at 7 WAP; the soil amended with NPK gave significantly taller plant at 9 WAP. The two okra varieties significantly differed in their heights only at 3 and 5 WAP in 2010; LD 88-1 was significantly taller than NHAe 47-4 at both measurement periods (Table 3). There was no significant interaction effect of soil amendment and variety on the height of the plant in both seasons of study. The result of the effects of the soil amendments on the number of leaves of okra in the two years of the study is as presented in Table 4 . In both years, significant effect of soil amendment was noticed at 9 WAP while varietal differences in leaf number were apparent at 5 and 7 WAP in the first season only. $\mathrm{P} 3$ resulted in the highest number of leaves per 
TABLE 5: Effects of cured organic soil amendment on the mean leaf area $\left(\mathrm{cm}^{2}\right)$ of okra in 2010 and 2011 cropping seasons.

\begin{tabular}{|c|c|c|c|c|c|c|c|c|}
\hline \multirow{2}{*}{ Treatment } & \multicolumn{2}{|c|}{$3 \mathrm{WAP}$} & \multicolumn{2}{|c|}{5 WAP } & \multicolumn{2}{|c|}{7 WAP } & \multicolumn{2}{|c|}{9 WAP } \\
\hline & 2010 & 2011 & 2010 & 2011 & 2010 & 2011 & 2010 & 2011 \\
\hline \multicolumn{9}{|c|}{ Soil amendment } \\
\hline $\mathrm{C} 3$ & 37.4 & 32.0 & 40.9 & 38.3 & 72.6 & 66.9 & 69.8 & 70.5 \\
\hline C6 & 37.0 & 26.7 & 44.9 & 34.2 & 70.2 & 53.7 & 83.3 & 84.5 \\
\hline C9 & 41.8 & 26.7 & 51.7 & 35.2 & 74.9 & 57.0 & 77.2 & 71.0 \\
\hline $\mathrm{P} 3$ & 68.8 & 58.3 & 76.4 & 80.4 & 119.1 & 113.4 & 124.3 & 107.2 \\
\hline P6 & 58.8 & 43.9 & 73.0 & 59.4 & 102.4 & 89.3 & 102.4 & 91.1 \\
\hline P9 & 48.6 & 39.3 & 55.9 & 46.6 & 91.8 & 70.8 & 71.7 & 74.1 \\
\hline NA & 29.8 & 21.3 & 33.8 & 28.7 & 58.7 & 49.4 & 56.6 & 63.9 \\
\hline NPK & 55.0 & 40.3 & 63.2 & 50.2 & 103.2 & 86.3 & 92.7 & 90.4 \\
\hline $\mathrm{SE} \pm$ & 6.38 & 6.64 & 7.08 & 7.65 & 9.50 & 9.95 & 11.07 & 11.56 \\
\hline $\operatorname{LSD}_{(0.05)}$ & 12.85 & 12.94 & 14.25 & 15.42 & 19.14 & 20.04 & 22.30 & 23.28 \\
\hline \multicolumn{9}{|l|}{ Variety } \\
\hline LD 88-1 & 42.9 & 31.1 & 52.0 & 42.1 & 77.6 & 69.9 & 82.9 & 78.7 \\
\hline NHAe $47-4$ & 51.4 & 40.8 & 57.9 & 51.1 & 95.6 & 76.9 & 86.6 & 84.5 \\
\hline $\mathrm{SE} \pm$ & 3.19 & 3.21 & 3.54 & 3.83 & 4.75 & 4.98 & 5.53 & 5.78 \\
\hline $\operatorname{LSD}_{(0.05)}$ & 6.43 & 6.47 & ns & 7.71 & 9.57 & ns & ns & ns \\
\hline
\end{tabular}

ns: not significant; LSD: least significant difference $(p=0.05)$; WAP: weeks after planting; SE: standard error.

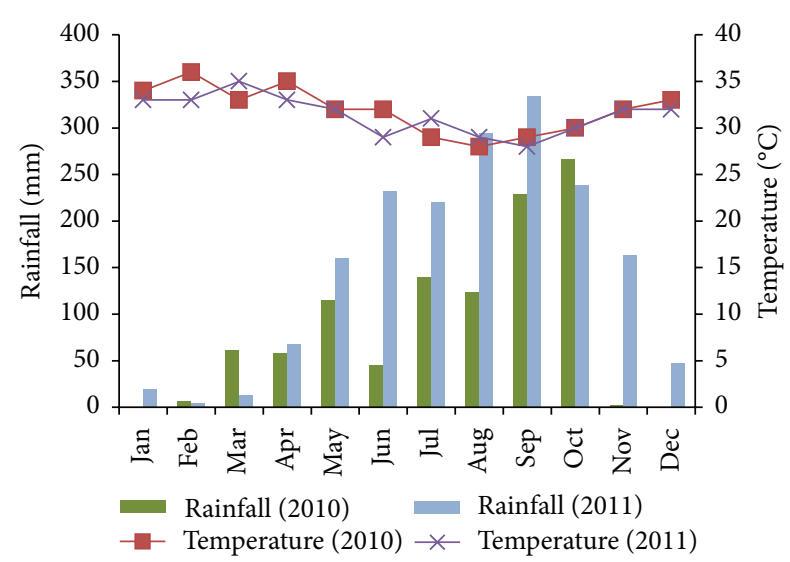

FIgURE 1: Average monthly rainfall and temperature of the experimental site for the 2010 and 2011 cropping seasons.

plant in both years, though not significantly different from the result obtained from the soil amended with NPK. LD 881 had more number of leaves per plant at both measurement periods in 2010. There was no significant interaction effect.

The leaf area of okra was significantly affected by soil amendments at all the measurement periods in the two years of assessment. P3 produced the highest leaf areas for the two cropping seasons (Table 5). Significant variation was also observed in the leaf areas among the two varieties at 3 and 5 WAP in both years, as well as at 7 WAP in 2010. In all cases, NHAe 47-4 produced broader leaves compared to LD 88-1 (Table 5).

The days to first flowering in okra were not significantly affected by the soil amendments. All treatments also attained $50 \%$ flowering at about 45 days after planting in both years (Table 6). The two varieties evaluated differ significantly in
TABLE 6: Effects of cured organic amendments and varieties on okra flowering characteristics in 2010 and 2011 cropping seasons.

\begin{tabular}{lcccc}
\hline \multirow{2}{*}{ Treatment } & \multicolumn{3}{c}{ Days to flowering (DAP) } & \multicolumn{3}{c}{$50 \%$ flowering (DAP) } \\
& 2010 & 2011 & 2010 & 2011 \\
\hline Soil amendment & & & & \\
C3 & 37 & 40 & 44 & 45 \\
C6 & 38 & 41 & 44 & 46 \\
C9 & 37 & 41 & 43 & 46 \\
P3 & 36 & 41 & 42 & 47 \\
P6 & 39 & 42 & 44 & 47 \\
P9 & 38 & 40 & 43 & 45 \\
NA & 38 & 42 & 44 & 46 \\
NPK & 39 & 41 & 44 & 47 \\
SE \pm & 1.126 & 1.024 & 0.922 & 1.14 \\
LSD & ns.05) & $n s$ & $n s$ & $n s$ \\
Variety & & & & \\
LD 88-1 & 41 & 43 & 47 & 48 \\
NHAe 47-4 & 34 & 39 & 40 & 44 \\
SE $\pm_{\text {LSD }}$ & 0.563 & 0.512 & 0.461 & 0.592 \\
\hline
\end{tabular}

ns: not significant; LSD: least significant difference ( $p=0.05)$; DAP: days after planting; SE: standard error.

the number of days to first flowering $(p<0.05)$ in the two cropping seasons. While the first flower appeared 34 days after planting in NHAe 47-4, it took LD 88-1 about 41 days to attain the same status. Similarly, the $50 \%$ flowering was attained in NHAe $47-4$ at 40 days in 2010 while LD 88-1 attained $50 \%$ flowering at 47 days in the same year. In 2011, 
TABLE 7: Effects of cured organic amendments and varieties on pod characteristics and yield in 2010 and 2011 cropping seasons.

\begin{tabular}{|c|c|c|c|c|c|c|c|c|}
\hline \multirow{2}{*}{ Treatment } & \multicolumn{2}{|c|}{ Number of grooves per pod } & \multicolumn{2}{|c|}{ Fruit length $(\mathrm{cm})$} & \multicolumn{2}{|c|}{ Fruit weight per pod (g) } & \multicolumn{2}{|c|}{ Cumulative yield $\left(\mathrm{t} \mathrm{ha}^{-1}\right)$} \\
\hline & 2010 & 2011 & 2010 & 2011 & 2010 & 2011 & 2010 & 2011 \\
\hline \multicolumn{9}{|c|}{ Soil amendment } \\
\hline $\mathrm{C} 3$ & 7.49 & 7.84 & 5.71 & 5.76 & 46.5 & 57.1 & 1.40 & 1.71 \\
\hline C6 & 7.42 & 7.66 & 5.82 & 5.31 & 55.3 & 68.5 & 1.69 & 2.06 \\
\hline $\mathrm{C} 9$ & 7.54 & 7.58 & 5.81 & 5.64 & 63.8 & 60.8 & 1.55 & 1.82 \\
\hline P3 & 7.58 & 7.67 & 5.88 & 5.60 & 82.9 & 85.6 & 2.58 & 2.57 \\
\hline P6 & 7.51 & 7.66 & 5.83 & 5.60 & 55.5 & 85.4 & 2.03 & 2.56 \\
\hline P9 & 7.51 & 7.41 & 5.58 & 5.08 & 57.6 & 70.9 & 1.65 & 2.13 \\
\hline NA & 7.11 & 7.33 & 5.47 & 5.17 & 38.5 & 29.8 & 1.17 & 0.89 \\
\hline NPK & 7.78 & 7.90 & 6.03 & 6.16 & 57.1 & 72.5 & 1.60 & 2.17 \\
\hline $\mathrm{SE} \pm$ & 0.268 & 0.336 & 0.269 & 0.337 & 7.18 & 11.79 & 0.194 & 0.354 \\
\hline $\operatorname{LSD}_{(0.05)}$ & ns & ns & ns & ns & 14.76 & 23.74 & 0.390 & 0.713 \\
\hline \multicolumn{9}{|l|}{ Variety } \\
\hline LD 88-1 & 7.23 & 7.79 & 5.76 & 5.41 & 56.2 & 60.1 & 1.63 & 1.80 \\
\hline NHAe $47-4$ & 7.74 & 7.42 & 5.77 & 5.68 & 58.1 & 72.5 & 1.73 & 2.18 \\
\hline $\mathrm{SE} \pm$ & 0.134 & 0.168 & 0.135 & 0.168 & 3.59 & 5.89 & 0.097 & 0.177 \\
\hline $\operatorname{LSD}_{(0.05)}$ & 0.269 & 0.338 & $\mathrm{~ns}$ & ns & ns & 11.87 & 0.195 & 0.356 \\
\hline
\end{tabular}

ns: not significant; LSD: least significant difference $(p=0.05)$; SE: standard error.

NHAe $47-4$ attained 50\% flowering within 44 days and LD $88-1$ at 48 days after planting.

The result of the effect of soil amendment on pod characteristics as presented in Table 7 shows no significant difference in the number of pod grooves and pod length among the soil amendment treatments in the two cropping seasons. The varieties also did not differ significantly in terms of pod length but the variety NHAe 47-4 had higher number of grooves per pod than LD 88-1 in 2010, while the reverse was the case in 2011. Fruit weight varied among the soil amendments in both years of the study. P3 supported significantly higher fruit weight when compared with other soil treatments. Significant variation in the fruit weight was also observed among the two varieties in 2011, with the variety NHAe 47-4 having higher value.

Cumulative yield revealed a significant difference among the soil amendment treatments in the two years of the study. In both seasons, $\mathrm{P} 3$ gave the best cumulative yield (2.58 and $2.57 \mathrm{t} \mathrm{ha}^{-1}$, resp.). Also, NHAe $47-4$ gave better yield (1.73 and $2.18 \mathrm{tha}^{-1}$ ) than LD 88-1 (1.63 and $1.80 \mathrm{tha}^{-1}$ ) in the years 2010 and 2011, respectively. The percentage change in yield of okra over NPK due to the application of the variously cured organic manures indicated that, in 2010, P3 produced $61.25 \%$ yield increase above NPK; P6 had 26.88\%, C6 had 5.63\%, and P9 produced 3\% additional yield above the standard (NPK). Similarly, in 2011, P3 resulted in the highest yield increase $(18.43 \%)$ over standard. The relative yield increase over control were higher for the plots supported with P3, P6, and C6 in 2010, while, in 2011, only P3 and P6 gave higher yield increase (Table 8).

\section{Discussion}

The positive response of okra to the application of cured organic manure, most especially $\mathrm{P} 3$, in terms of height and
TABLE 8: Relative yield change over standard and relative yield increase over control in the yield of okra in 2010 and 2011 cropping seasons.

\begin{tabular}{lcccc}
\hline \multirow{2}{*}{ Treatment } & \multicolumn{2}{c}{$\begin{array}{c}\text { Yield change } \\
\text { over standard (\%) }\end{array}$} & \multicolumn{2}{c}{$\begin{array}{c}\text { Yield increase over } \\
\text { the control (\%) }\end{array}$} \\
& 2010 & 2011 & 2010 & 2011 \\
\hline C3 & 87.50 & 78.80 & 53.49 & 64.06 \\
C6 & 105.63 & 94.93 & 120.93 & 91.41 \\
C9 & 96.88 & 83.87 & 88.37 & 72.66 \\
P3 & 161.25 & 118.43 & 327.91 & 131.25 \\
P6 & 126.88 & 117.97 & 200.00 & 130.47 \\
P9 & 103.13 & 98.16 & 111.63 & 96.88 \\
NA & 73.13 & 41.01 & 0.00 & 0.00 \\
NPK & 100.00 & 100.00 & 100.00 & 100.00 \\
\hline
\end{tabular}

number of leaves per plant, as observed in this study, can be attributed to the stage of decomposition of the organic manure used. Due to the curing periods, the nutrients in the manure were already at the stage when they can be released gradually and slowly for plant absorption and utilization. Schlegel [12] had earlier reported that the use of chicken or poultry manure in soil amendment resulted in taller plants and higher number of leaves per plant in grain sorghum because of its high content of nitrogen, phosphorus, and potassium. The higher number of leaves and leaf area at 9 WAP in both years are indications that organic manure supplies the required nutrients to the plants a little later than what was obtained with the inorganic fertilizer. Similar result was reported by Okokoh and Bisong [13] who obtained taller and more leafy plants of Amaranthus cruentus with plots treated with $15 \mathrm{tha}^{-1}$ of poultry manure than those treated with urea $\left(20 \mathrm{~kg} \mathrm{ha}^{-1}\right)$. In an earlier study, Masarirambi et al. 
[14] had observed that chicken manure fertilized plants were taller and had relatively higher average number of leaves per plant, followed in decreasing order by cattle manure and inorganic fertilizer.

The pod and yield characteristics observed in this study can be attributed to the better supply of nutrients by the organic manures resulting in better growth and development by the plants culminating in good yield. Maheshbabu et al. [15] stated that manure acts as nutrient reservoir and upon decomposition; the nutrients are released slowly during the entire growth periods leading to better growth and higher yield. The consistent release of nutrients, which are made available for the use of the plants throughout their growth period, gives organic manure an edge over inorganic fertilizer.

The higher pod yield obtained in this study from poultry droppings cured for 3 and 6 weeks (P3 and P6, resp.), compared to other treatments, could be attributed to the increase in $\mathrm{N}$ and $\mathrm{K}$ uptake by the okra plants. Majanbu et al. [16] had shown that $\mathrm{N}$ and $\mathrm{K}$ are the most important macronutrients that okra requires for proper growth and pod production, and poultry manure has been reported to be high in $\mathrm{N}, \mathrm{P}$, and $\mathrm{K}$ with the majority of these nutrients (about $75 \%$ of $\mathrm{N}$ and $90-100 \%$ of $\mathrm{P}$ and $\mathrm{K}$ ) being made available to plant [17]. Vegetables, generally, have been reported to benefit immensely from the $\mathrm{N}$ and $\mathrm{P}$ and other micronutrients found in organic manures [18].

The differences observed among the two varieties could be attributed to their genetic make-up since no significant amendment $\times$ variety interaction was observed in the study. Ibrahim et al. [19] affirmed that differential growth of crops under similar environmental conditions is normally the result of differences in the genetic make-up of these crops. The yield differences observed among the two varieties corroborates the work of Akinfosoye et al. [20] who observed significant variation in the yield of okra varieties. They attributed this observation to the choice of cultivar grown and its specific genetic make-up.

\section{Conclusion}

This study has revealed that the application of organic amendment cured for 3 to 6 weeks before application enhanced the growth and yield of okra when compared with inorganic fertilizer or the unamended soil. The variety NHAe 47-4 has also been demonstrated to give better yield (1.73 and $2.18 \mathrm{tha}^{-1}$ ) than LD 88-1 (1.63 and $1.80 \mathrm{tha}^{-1}$ ) in the years 2010 and 2011, respectively. The general performance of variety NHAe 47-4 was shown to be better across all soil amendment treatments in the two years of the study. Based on the outcome of this study, the use of adequate quantity of livestock droppings cured for 3-6 weeks, in case of poultry dropping, and for 6 weeks, in case of cow dung, is recommended as a better alternative to inorganic fertilizer, especially in the tropics.

\section{Conflict of Interests}

The authors declare that there is no conflict of interests regarding the publication of this paper.

\section{References}

[1] J. S. Siemonsma, The cultivation of okra (Abelmoschus spp.), (with reference to the Ivory Coast) [D.H.O. thesis], Wageningen Agricultural University, Wageningen, The Netherland, 1982.

[2] R. A. Sobulo, "Fertilizer use and soil testing in Nigeria," in Agronomy in Nigeria, M. O. Akoroda, Ed., pp. 195-201, Department of Agronomy, University of Ibadan, Ibadan, Nigeria, 2000.

[3] M. A. Awodun, "Effect of nitrogen released from rumen digesta and cow dung on soil and leaf nutrient content of Gboma (Solanummacrocarpon)," Journal of Applied Biosciences, vol. 7, pp. 202-206, 2008.

[4] V. M. Mayong, J. G. K. Webster, S. S. Jagtap, and B. Oyewole, Macro Characterization of Agricultural Systems in West Africa. An Overview, Resource and Crop Management Monograph, No. 21, IITA, Ibadan, Nigeria, 1996.

[5] M. Akiri, "Bill gates foundation boosts soil fertility project with .5m," The Nation Daily Newspaper, Nigeria, 2011.

[6] D. T. Avery, Saving the Planet with Pesticides and Plastic: The Environmental Triumph of High-Yielding Farming, Hudson Institute, Indianapolis, Ind, USA, 1995.

[7] C. A. Palm and P. A. Sanchez, "Nitrogen release from the leaves of some tropical legumes as affected by their lignin and polyphenolic contents," Soil Biology and Biochemistry, vol. 23, no. 1, pp. 83-88, 1991.

[8] D. W. Reeves, "The role of soil organic matter in maintaining soil quality in continuous cropping systems," Soil and Tillage Research, vol. 43, no. 1-2, pp. 131-167, 1997.

[9] International Institute for Tropical Agriculture (IITA), Selected Methods for Soil and Plant Analysis, IITA Manual Series no. 1, International Institute for Tropical Agriculture (IITA), Ibadan, Nigeria, 1979.

[10] S. H. Chien, P. W. G. Sale, and D. K. Friesen, "A discussion of the methods for comparing the relative effectiveness of phosphate fertilizers varying in solubility," Fertilizer Research, vol. 24, no. 3, pp. 149-157, 1990.

[11] VSN International, Genstat Release 10.3 DE, VSN International, Rothamsted Experimental Station, 2011.

[12] A. J. Schlegel, "Effect of composted manure on soil chemical properties and nitrogen use by grain sorghum," Journal of Production Agriculture, vol. 5, no. 1, pp. 153-157, 1992.

[13] S. J. Okokoh and B. W. Bisong, "Effect of poultry manure and urea- $\mathrm{N}$ on flowering occurrence and leaf productivity of Amaranthuscruentus," Journal of Applied and Environmental Science Management, vol. 15, pp. 13-15, 2011.

[14] M. Masarirambi, M. Hlawe, O. Oseni, and T. Sibiya, "Effects of organic fertilizers on growth, yield, quality and sensory evaluation of red lettuce (Lactuca sativa L.) 'Veneza Roxa,' Agriculture and Biology Journal of North America, vol. 1, no. 6, pp. 1319-1324, 2010.

[15] H. M. Maheshbabu, H. Ravs, N. K. Biradar, and H. B. Babalad, "Effect of organic manure on plant growth, seed yield and quality of soybean," Karnataka Journal of Agricultural Sciences, vol. 21, pp. 219-221, 2007.

[16] I. S. Majanbu, V. B. Ogunlela, and M. K. Ahmed, "Response of two okra (Abelmoschus esculentus L. Moench) varieties to fertilizers: growth and nutrient concentration as influenced by nitrogen and phosphorus application," Fertilizer Research, vol. 8, no. 3, pp. 297-306, 1986.

[17] M. Risse, "Land application of livestock and poultry manure," 2015, http://extension.uga.edu/publications/files/pdf/ C\%20826_4.PDF. 
[18] D. S. Robinson, Food Biochemistry and Nutritional Value, Longman Scientific and Technical, New York, NY, USA, 1990.

[19] K. Ibrahim, A. Amaus, and I. U. Abubakar, "Growth indices and yield of tomatoes (Lycopersiconesculentus Mill.). varieties as influenced by crop spacing at Samaru," in Proceedings of the 8th Annual Conference of Horticultural Society of Nigeria, pp. 40-47, Ibadan, Nigeria, November 2000.

[20] J. A. Akinfosoye, A. O. Olufolaji, F. M. Tairu, and R. A. Adewoola, "Effect of different phosphorus levels on the yield of four cultivars of rain-fed tomato (Lycopersiconesculentum Mill.)," in Proceedings of the 15th Annual Conference of Horticultural Society of Nigeria (HORTSON '97), pp. 65-66, Ibadan, Nigeria, 1997. 


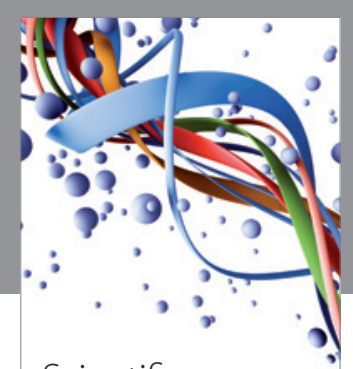

Scientifica
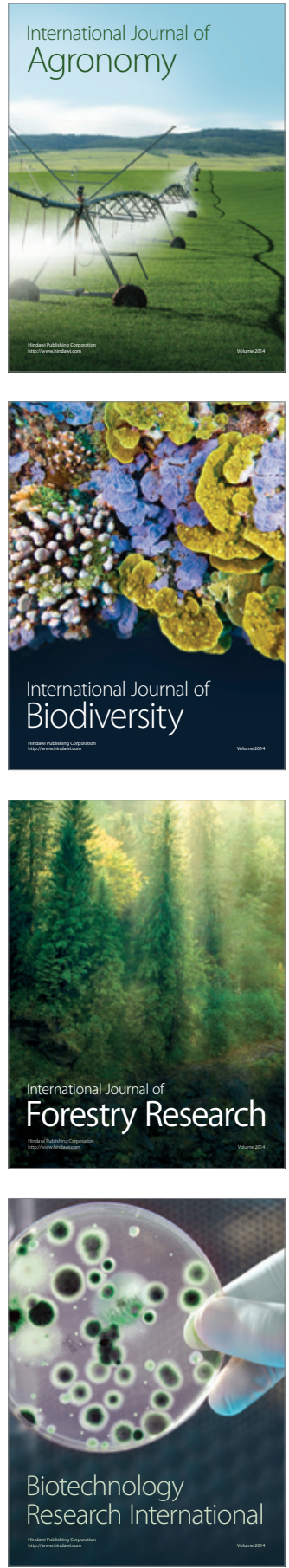
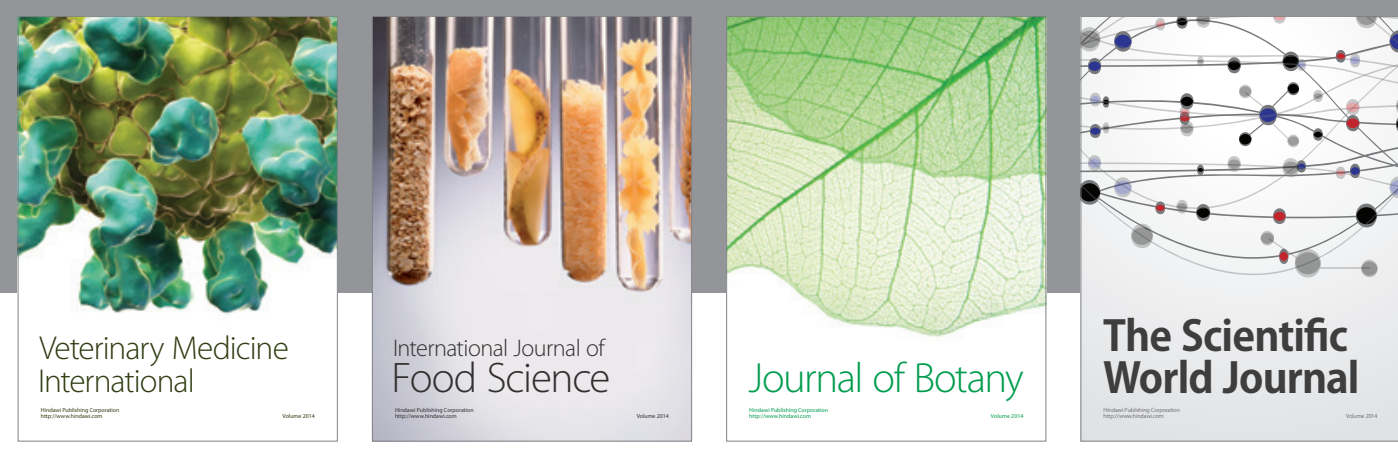

The Scientific

\section{World Journal}

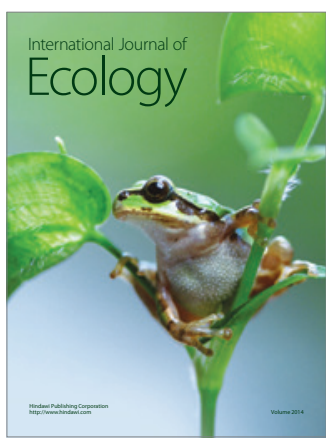

\section{Hindawi}

Submit your manuscripts at

http://www.hindawi.com
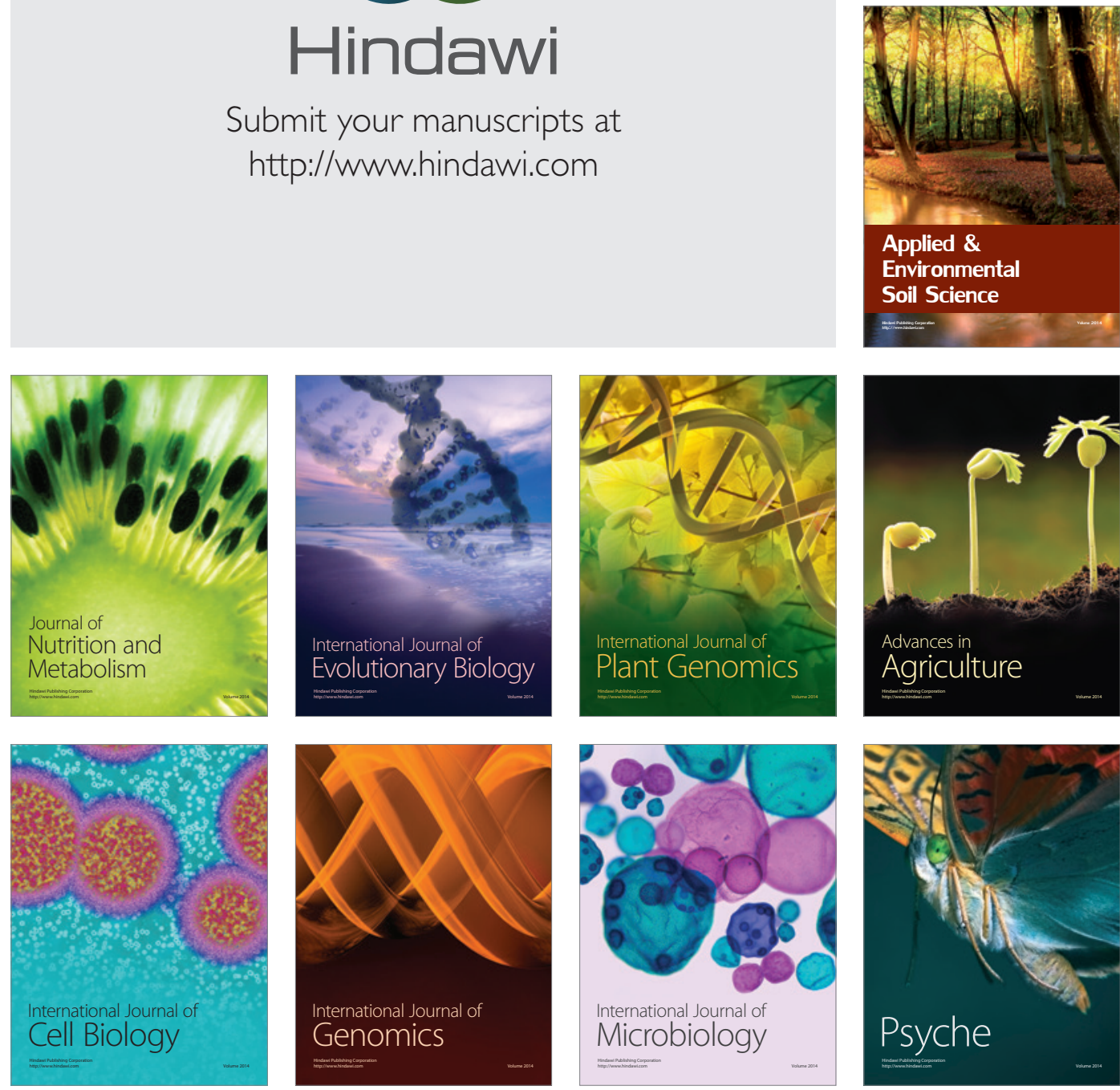
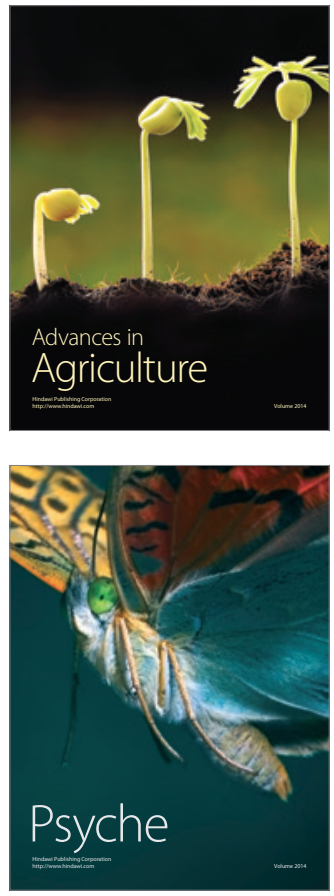